\title{
GFS, a preparation of Tasmanian Undaria pinnatifida is associated with healing and inhibition of reactivation of Herpes Russell Cooper ${ }^{1}$, Charles Dragar ${ }^{2}$, Kate Elliot ${ }^{3}$, JH Fitton*4, John Godwin ${ }^{5}$ and Ken Thompson 6
}

Address: ${ }^{1}$ Anubha Mountain Health Retreat. 680 Summerleas Road, Kingston, Tasmania, Australia, ${ }^{2}$ Novost Pty Ltd, 53 Channel Highway, Kingston, Tasmania 7050, Australia, ${ }^{3}$ Suite 105, 86 Murray Street, Hobart Tasmania, ${ }^{4}$ Marine Biomedical Research Level 10, 39 Murray Street, Hobart, Tasmania 7000, Australia, ${ }^{5}$ Healing World 124, 16th Avenue Tauranga, New Zealand and ${ }^{6}$ Department of Pathology, University of Chicago, USA

E-mail: Russell Cooper - anubha@southcom.com.au; Charles Dragar - mail@novost.com.au; Kate Elliot - helen.fitton@marineresources.com.au; JH Fitton* - helen.fitton@marineresources.com.au; John Godwin - John.Godwin@clearnet.net.nz; Ken Thompson - Thompson@midway.uchicago.edu

${ }^{*}$ Corresponding author

Published: 20 November 2002

BMC Complementary and Alternative Medicine 2002, 2:1 I
Received: 21 June 2002

Accepted: 20 November 2002

This article is available from: http://www.biomedcentral.com/I472-6882/2/II

(C) 2002 Cooper et al; licensee BioMed Central Ltd. This article is published in Open Access: verbatim copying and redistribution of this article are permitted in all media for any purpose, provided this notice is preserved along with the article's original URL.

\begin{abstract}
Background: We sought to assess whether GFS, a proprietary preparation of Tasmanian Undaria pinnatifida, has effects on healing or re-emergence of Herpetic infections, and additionally, to assess effects of GFS in vitro. Undaria is the most commonly eaten seaweed in Japan, and contains sulphated polyanions and other components with potential anti-viral activity. Herpes simplex virus type I (HSV-I) infections have lower reactivation rates and Herpes type 2 (HSV-2) infections have lower incidence in Japan than in the west.
\end{abstract}

Methods: Patients with active (I5 subjects) or latent (6 subjects) Herpetic infections (HSV-I, 2, EBV, Zoster) were monitored for response to ingestion of GFS. GFS extract was tested in vitro for human $\mathrm{T}$ cell mitogenicity and anti-Herpes activity.

Results: Ingestion of GFS was associated with increased healing rates in patients with active infections. In addition, patients with latent infection remained asymptomatic whilst ingesting GFS. GFS extract inhibited Herpes viruses in vitro and was mitogenic to human T cells in vitro.

Conclusions: Ingestion of GFS has inhibitory effects on reactivation and is associated with increased rate of healing after Herpetic outbreaks. GFS extract potently inhibited Herpes virus in vitro, and had mitogenic effects on human T cells.

\section{Background}

Herpes viruses are important human pathogens, causing both primary and secondary infections that range from trivial mucosal ulcers to life threatening disorders in immuno-compromised patients $[1,2]$. The Herpes group includes HSV-1, HSV-2, Herpes Zoster (chicken pox/ shingles), HCMV (human cytomegalovirus), EBV, Herpes 6, 7 (Roseola, post transplant infections) and Herpes 8 (associated with Kaposi sarcoma). The conventional treatment of these infections is with drugs such as acyclovir (ACV) that target the viral DNA polymerase. Whilst these drugs are undoubtedly efficient, their long-term use has 
led to the development of resistant viral strains that now comprise $5 \%$ of all HSV infections in immuno-compromised patients [1]. Finding non-toxic alternatives to these drugs is of interest to patients and to drug companies investigating more effective remedies. Whilst the epidemiology and serotype of Herpes infections varies widely within the world community, as a result of differing subpopulations and childhood exposure rates, it seems that the incidence of HSV2 in Japanese women is substantially less than that of American women. (e.g., 50\% seroprevalence in one study of African-American women vs. $7 \%$ in Japan) [3]. We also noted that the reactivation of Herpes simplex I (HSV-1) as measured by shedding [4] is considerably less in the Japanese population than in the west. However, EBV, some strains of which are associated with malignancies, affects over $90 \%$ of the population world wide [5], and seropositivity for CMV is higher in the Japanese population [6].

Several plants have been shown to have anti-viral activity, but edible brown marine algae are unique in that they are a regular part of the Japanese daily diet. Key anti-viral active agents within brown algae are the sulphated polyanions [7-9]. In recent years both natural and synthetic sulphated polyanions have been a research focus for their potential therapeutic activity. They are considered to act principally by inhibiting the entry of coated viruses such as Herpes into host cells [7-9], by competing for receptors at the cell surface. This activity is, in part, due to the similarities of the algal polyanions to mammalian heparin sulphate molecules. There are a number of receptors (including a heparin sulphate receptor) expressed differentially on various cell types, which provide entry points for Herpes viruses [10]. This mechanism of inhibition contrasts with that of commonly used drugs such as ACV which act as nucleic acid inhibitors, preventing viral replication after the virus has entered the cell.

The main seaweed in the Japanese daily diet is Undaria pinnatifida, commonly known as 'wakame' [11]. The major sulphated polyanion present in Undaria is characterised as a 'galactofucan sulphate' $[12,13]$. Other sulphated polyanions such as the synthetic dextran sulphates, pentosan sulphates, clinically used heparins, and seaweed-derived carageenans have all been investigated for anti-viral activity in humans, either systemically or topically [7-9]. However, to date, Undaria ingestion has not been clinically assessed in a western population for its effects on common coated viruses such as HSV-1 and 2 which have reduced incidence in the Japanese population $[3,4]$. Undaria extracts have been shown to have anti-viral effects on HSV-1 in vitro [14] and also against the Herpes group virus Epstein Barr Virus or EBV [15]. Specific molecules were not identified in these studies, thus the observed anti-viral activity may arise from either or both polyanions and oth- er components. Undaria aqueous extract (made by boiling Undaria in water) and a partially purified galactofucan sulphate extract were recently assessed for activity against clinical isolates of Herpes I and Herpes II in vitro $[16,17]$. Twenty of the viral strains were sensitive to ACV, and nineteen were resistant. In the test, both types of extract were active against all strains, and more active against strains of HSV-2 than strains of HSV-1. The mode of action was shown to be blocking attachment and entry of HSV into the host cells.

Undaria fractions have also been shown to have immune stimulating qualities in vitro [18] and other brown seaweed fractions have been shown to have immunological effects in vivo $[19,8,9]$.

The mechanism of viral inhibition by polyanions such as galactofucan does not generate resistant strains at the same rates as ACV [7]. Aside from the inhibition of viral infectivity, it is possible that immune stimulation via polyanions or other components, increases anti-viral activity $[18,19]$

We hypothesised that Undaria ingestion may be associated with resolution of Herpes infections in a western population, and that this would be reflected by inhibition of HSV infectivity and increased T cell activity in vitro. In this study, a proprietary Undaria preparation 'GFS' was assessed for effects on the healing of, and the inhibition of outbreaks of HSV infections in otherwise healthy patients. In addition, whole aqueous extracts of the GFS were assessed for effects on HSV infectivity in vitro and on human $\mathrm{T}$ cell stimulation in vitro.

\section{Methods \\ A) GFS}

GFS was prepared from Tasmanian Undaria pinnatifida and supplied in $560 \mathrm{mg}$ capsules by Marine Resources Pty Ltd. It comprises solely of the alga, processed to complete dryness in the dark within a day of harvest, in hygienic conditions. Batches were milled and mixed to ensure uniformity.

\section{B) Patient study}

Seventeen patients were recruited for the study by health practitioners. Patients gave verbal informed consent to the study. Health practitioners monitored the patients' health. There are no known adverse effects related to the ingestion of Undaria. No other anti-viral medications were taken at the same time as GFS. The duration of the study was from one month to 24 months. Patient ages were from less than 10 years up to 72 years.

In total, seven cases of HSV-1, five cases of HSV-2, three of active Herpes zoster (one chicken pox, two shingles) and 
Table I: Patients with active Herpes infections

\begin{tabular}{|c|c|c|c|c|c|c|c|}
\hline Patient & Sex & Age & Virus & Site infection & $\begin{array}{l}\text { Resolution of } \\
\text { infection? }\end{array}$ & $\begin{array}{l}\text { If on } \\
\text { maintenance, } \\
\text { Inhibition of } \\
\text { outbreaks? }\end{array}$ & Comment \\
\hline I & M & 50 & HSVI & Orolabial & $\begin{array}{l}\text { Yes, no progression to } \\
\text { lesion }\end{array}$ & $\begin{array}{l}\text { Yes, inhibition of } \\
\text { further outbreaks } \\
\text { on maintenance } \\
\text { dose }>2 \text { years. }\end{array}$ & $\begin{array}{l}\text { Varied dosage, consistent } \\
\text { inhibition. }\end{array}$ \\
\hline 2 & $\mathrm{~F}$ & 14 & HSVI & Orolabial & $\begin{array}{l}\text { Yes, very severe } \\
\text { outbreak resolved within } \\
\text { course. }\end{array}$ & $\mathrm{N} / \mathrm{a}$ & $\begin{array}{l}\text { Patient noted rapid reduction } \\
\text { in pain. }\end{array}$ \\
\hline 3 & $\mathrm{~F}$ & 72 & HSVI prodrome & $\begin{array}{l}\text { Orolabial } \\
\text { (prodrome) } \\
\text { and ocular } \\
\text { conjunctiva }\end{array}$ & $\begin{array}{l}\text { Yes, no progression to } \\
\text { lesion }\end{array}$ & $\begin{array}{l}\text { Yes, continued } \\
\text { Inhibition of low } \\
\text { grade conjunctival } \\
\text { HSVI for three } \\
\text { months }\end{array}$ & $\begin{array}{l}\text { Notes improvement in skin } \\
\text { condition. }\end{array}$ \\
\hline 4 & M & 40 & HSVI prodrome & Orolabial & Yes, in normal time. & $N / a$ & $\begin{array}{l}\text { Not taken consistently. No } \\
\text { benefit noted but no spread } \\
\text { of lesion. }\end{array}$ \\
\hline 5 & $\mathrm{~F}$ & 50 & HSVI active lesion & Orolabial & Yes, in normal time & $N / a$ & $\begin{array}{l}\text { No spread of lesion and pain } \\
\text { reduced. Took half dose only. }\end{array}$ \\
\hline 6. & $\mathrm{~F}$ & 47 & HSVI & Orolabial & $\begin{array}{l}\text { Yes, reduction in lesion } \\
\text { severity }\end{array}$ & $N / a$ & $\begin{array}{l}\text { No recurrence, no spread of } \\
\text { lesion. }\end{array}$ \\
\hline 7. & $\mathrm{~F}$ & 47 & HSVI & Orolabial & $\begin{array}{l}\text { Yes, rapid clearance } \\
\text { compared to previous. }\end{array}$ & $N / a$ & $\begin{array}{l}\text { Post chemotherapy outbreak } \\
\text { (breast cancer) }\end{array}$ \\
\hline 8 & $\mathrm{~F}$ & 20 & HSVII & Genital & Yes, lesions cleared. & $\mathrm{N} / \mathrm{a}$ & \\
\hline 9 & $F$ & 42 & HSVII & Genital & $\begin{array}{l}\text { Yes. Existing lesion } \\
\text { healed. }\end{array}$ & $\begin{array}{l}\text { Yes, inhibition of } \\
\text { further outbreaks } \\
\text { on maintenance } \\
\text { dose } 3 \text { mths. }\end{array}$ & $\begin{array}{l}\text { Prior two weekly outbreaks } \\
\text { of ACV resistant strain of } \\
\text { HSVII. }\end{array}$ \\
\hline 10 & $\mathrm{~F}$ & 23 & HSVII & Genital & $\begin{array}{l}\text { Yes, chronic lesion } \\
\text { healed }\end{array}$ & $\mathrm{N} / \mathrm{a}$ & \\
\hline II & $\mathrm{F}$ & 17 & EBV & systemic & Yes & $N / a$ & $\begin{array}{l}\text { Normal blood exam after } 4 \\
\text { days course. }\end{array}$ \\
\hline 12 & $\mathrm{~F}$ & $<10$ & EBV & Systemic & $\begin{array}{l}\text { Yes, EBV symptoms } \\
\text { absent at ten days }\end{array}$ & $N / a$ & $\begin{array}{l}\text { Three capsules per day } \\
\text { Chronic sinus infection also } \\
\text { cleared }\end{array}$ \\
\hline 13 & $\mathrm{~F}$ & 85 & Zoster (shingles) & Torso & Yes & $\begin{array}{l}\text { Yes, inhibition for } \\
\text { two months. }\end{array}$ & $\begin{array}{l}\text { Relief from lesions at } 4 \\
\text { capsules per day }\end{array}$ \\
\hline 14. & $M$ & Adult & Zoster (chicken pox) & $\begin{array}{l}\text { Whole body } \\
\text { sores }\end{array}$ & Yes & $\mathrm{N} / \mathrm{a}$ & $\begin{array}{l}\text { Pain reduction, rapid clearing } \\
\text { of lesions. }\end{array}$ \\
\hline 15 & $M$ & 40 & Zoster (shingles) & $\begin{array}{l}\text { T7,8, } \\
\text { dermatome } \\
\text { Right side }\end{array}$ & Yes & $N / a$ & $\begin{array}{l}\text { Faster drying of lesions, } \\
\text { increased speed of cycle, no } \\
\text { change in pain }\end{array}$ \\
\hline
\end{tabular}

two of EBV were assessed. Results are presented in tables 1 and 2. Patients suffering from HSVI typically experienced lesions lasting ten days. Patients with HSVII had experienced recurrent events of varying severity, sometimes overlapping, of up to ten days in duration. One patient with shingles reported 'cycle' duration of over ten days. Others did not report on duration.

Dosage levels were chosen to fall within the limits of normal dietary seaweed ingestion in Japan. Fifteen patients with active Herpetic viral infections were given four 560 mg capsules of GFS per day for ten days as a 'therapeutic dose'. All patients except subject 14, table 1 (primary zoster infection) were suffering repeat outbreaks of known aetiology

Six patients with latent HSV-1 or 2 were given two capsules per day as a 'maintenance dose'. Four of these patients, identified by an asterisk *, were continuations of treatment after the active infection phase. One patient (subject 3, table 2) took four capsules per day. 
Table 2: Patients with latent Herpes infections.

\begin{tabular}{|c|c|c|c|c|c|c|c|}
\hline patient & $\operatorname{sex}$ & age & virus & $\begin{array}{l}\text { Site of } \\
\text { infection }\end{array}$ & $\begin{array}{l}\text { Also treated for active } \\
\text { infection? }\end{array}$ & $\begin{array}{l}\text { Inhibition of outbreak whilst on } \\
\text { maintenance dose? }\end{array}$ & Comments \\
\hline 1 & $M^{*}(I)$ & 50 & HSVI & Orolabial & $\begin{array}{l}\text { Yes Existing lesion } \\
\text { healed. }\end{array}$ & $\begin{array}{l}\text { Yes, inhibition of further } \\
\text { outbreaks on maintenance dose } \\
>2 \text { years. }\end{array}$ & $\begin{array}{l}\text { Varied dosage, consistent } \\
\text { inhibition. }\end{array}$ \\
\hline 2 & $\mathrm{~F}^{*}(3)$ & 72 & $\begin{array}{l}\text { HSVI } \\
\text { prodrome }\end{array}$ & $\begin{array}{l}\text { Orolabial } \\
\text { (prodrome) } \\
\text { and ocular } \\
\text { conjunctiva }\end{array}$ & $\begin{array}{l}\text { Yes, no progression to } \\
\text { lesion }\end{array}$ & $\begin{array}{l}\text { Yes, continued Inhibition of low } \\
\text { grade conjunctival HSVI for } \\
\text { three months }\end{array}$ & $\begin{array}{l}\text { Notes improvement in skin } \\
\text { condition. }\end{array}$ \\
\hline 3 & $F^{*}(13)$ & 85 & $\begin{array}{l}\text { Zoster } \\
\text { (shingles) }\end{array}$ & Torso & Yes & Yes, inhibition for two months. & $\begin{array}{l}\text { Relief from lesions requires } 4 \\
\text { capsules per day }\end{array}$ \\
\hline 4 & $\mathrm{~F}^{*}(9)$ & 42 & HSVII & Genital & $\begin{array}{l}\text { Yes. Existing lesion } \\
\text { healed. }\end{array}$ & $\begin{array}{l}\text { Yes, inhibition of further } \\
\text { outbreaks on maintenance dose } \\
3 \text { months. }\end{array}$ & $\begin{array}{l}\text { Prior two weekly outbreaks of } \\
\text { ACV resistant strain of HSVII. }\end{array}$ \\
\hline 5 & $\mathrm{~F}$ & 41 & HSVII & Genital & $\begin{array}{l}\text { No(not taken during } \\
\text { active infection) }\end{array}$ & $\begin{array}{l}\text { Yes, inhibition on two capsules } \\
\text { per day for I month. }\end{array}$ & $\begin{array}{l}\text { Did not take during active } \\
\text { lesion outbreak. }\end{array}$ \\
\hline 6 & $\mathrm{~F}$ & 36 & HSVII & Genital & $\begin{array}{l}\text { No(not taken during } \\
\text { active infection) }\end{array}$ & $\begin{array}{l}\text { Yes, inhibition on two capsules } \\
\text { per day for I month. }\end{array}$ & $\begin{array}{l}\text { Did not take during active } \\
\text { lesion outbreak. }\end{array}$ \\
\hline
\end{tabular}

* the number in brackets refers to the number assigned to the same patient in table I.

\section{C) In vitro effects on $\mathrm{HSV}$}

GFS was mixed 1:40 w/v with distilled water and boiled for 5 minutes. The liquid was filtered through a $0.45 \mu \mathrm{M}$ filter for sterilization and stored at -20 degrees Celsius. An aliquot of the preparation was dried and the weight was obtained to determine the concentration. The concentration used was the dry weight of the dissolved solids present.

Immortalized human fibroblasts, HF cells, were grown in Minimal Essential Media supplemented with glutamine, antibiotics, and $10 \%$ foetal bovine serum (FBS). Maintenance medium was supplemented with $1 \%$ FBS. Laboratory strains of HSV and HCMV (American type culture collection) were tested in this study. A stock of each virus was grown in cultured HF cells and aliquots were frozen at $-70^{\circ} \mathrm{C}$. The titre of each virus was determined by a plaque assay using HF cells in 24-well plates with an agarose overlay.

\section{D) $T$ cell stimulation in vitro}

$\mathrm{T}$ cell mitogenicity was evaluated by chromium uptake. Whole T cell preparations were obtained from buffy coats from pooled human blood samples. They were incubated in RPMI supplemented with $10 \%$ heat inactivated foetal calf serum, $5 \mathrm{mM} \mathrm{L}$-glutamine, $5 \times 10^{-5} \mathrm{M} 2$-mercaptoethanol and $30 \mathrm{U} / \mathrm{ml}$ gentamycin. Incubation for 72 hours was at $5 \% \mathrm{CO}_{2}, 37^{\circ} \mathrm{C}$ in 24 well plates. Cells were incubated with either GFS whole extract (at 25, 125 and $250 \mathrm{mcg}$ / $\mathrm{ml}$ as $1 \%, 5 \%$ or $10 \%$ of total culture volume prepared from a stock solution at $2.5 \mathrm{mg} / \mathrm{ml}$ ) or with the known mitogens (PHA) $(1 \mathrm{mcg} / \mathrm{ml})$ or Concanavalin A (ConA) $(1 \mathrm{mcg} / \mathrm{ml})$. Each concentration was assessed in triplicate $(\mathrm{n}=3)$

\section{Results \\ Patient study}

Results are presented in tables 1 and 2 .

\section{Active infection-table I}

All fifteen patients with active Herpetic viral infections experienced significant lessening or disappearance of symptoms. No adverse side effects were noted during the study.

Two patients (subjects 4 and 5, table 1 ) with noncompliant dosage regimes resolved infections in normal time, but noted no spread of lesions (as occurred during previous outbreaks). Reduction in lesion severity and rapid clearance were noted in two patients (subjects 6,7, table 1 ), and pain reduction as compared to previous events was noted by two patients (subjects 2,14, table 1 ). Two females with genital HSV-2 had persistent lesions which resolved during the course of treatment (subjects 8,10, table 1).

In two cases of diagnosed EBV, one clear at four and the other by ten days. In the latter patient a chronic sinus condition also cleared (subjects 11,12, table 1)

Over ten days, faster drying of zoster lesions and increased speed of normal cycle as compared to previous outbreaks was noted by a male patient (subject 15 , table 1 ) although 
no reduction in pain was reported. In an adult male suffering primary zoster (chicken pox) lesions of whole body (subject 14, table 1), pain reduction and rapid healing of lesions were noted. An elderly female patient noted a reduction in pain and visible skin lesions during the ten day course, and had no recurrence of symptoms whilst on a lower dose for the next two months.

\section{Latent infections-table 2}

All six patients on maintenance doses noted inhibition of further outbreaks of infection. No adverse side effects were noted during the study.

HSV-1 outbreaks were inhibited in two patients taking a maintenance dose over three months and two years respectively (subjects 1 and 2 in table 2). Low grade HSV-1 associated keratoconjunctivitis in the former patient was also inhibited

GFS ingestion correlated with inhibition of a previously persistent HSV-2 infection for three months in subject 4, table 2. In this patient, the infection was ACV resistant and outbreaks had been apparent on a two weekly basis for over a year.

HSV-2 outbreaks at the genital site were inhibited in two other female patients whilst taking a maintenance dose of two capsules per day, for one month (subjects 5,6, table 2).

Low grade recurrent Herpes zoster (shingles) lesions of the torso were inhibited for two months in an elderly patient whilst maintaining a dose of four capsules per day (subject 3, table 2).

\section{C) In vitro effects on HSV}

Herpes viruses were assessed for infectivity of human fibroblasts cells in vitro. Inhibition by GFS extract was noted as shown in table 3 .

Table 3: IC50 for GFS whole extract as measured by infectivity of HSVI, HSV2 and HCMV (human cytomegalovirus) in human fibroblasts.

\begin{tabular}{ll}
\hline Herpes virus & GFS I:40 w/v \\
\hline & \\
HSV - I, strain F & $3.1 \mathrm{ug} / \mathrm{ml}$ \\
HSV - 2, strain G & $1.6 \mathrm{ug} / \mathrm{ml}$ \\
HCMV, ADI69 & $2.5 \mathrm{ug} / \mathrm{ml}$ \\
HCMV, DI6 & $2.5 \mathrm{ug} / \mathrm{ml}$ \\
\hline
\end{tabular}

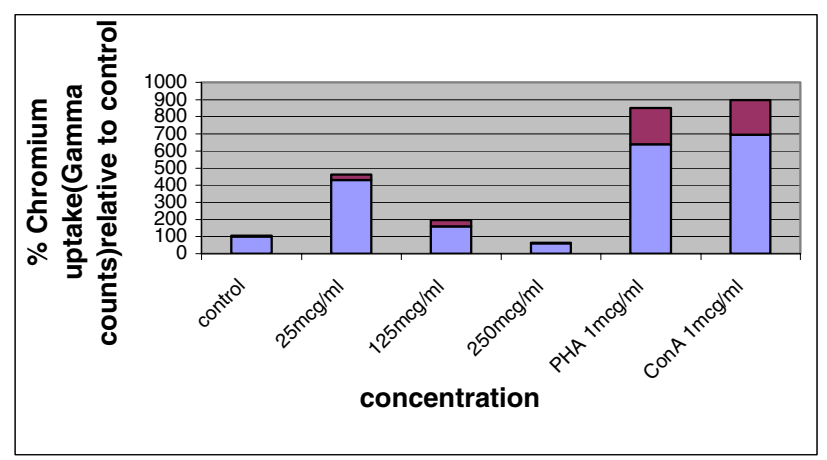

Figure I

$\mathrm{T}$ cell mitogenicity in the presence of GFS whole extract in vitro. GFS extract assessed at 25, I25, 250 micrograms $/ \mathrm{ml}$ (as $1 \%, 5 \%$ and $10 \%$ of culture medium from a stock solution at $2.5 \mathrm{mg} / \mathrm{ml}$ ). PHA and ConA were assessed at I mcg/ml. N $=3$ in all cases. Blue bars indicate average readings, red bars indicate standard deviations.

\section{D) $T$ cell stimulation in vitro}

GFS extract was assessed for effects on whole human T cell preparation in vitro. After incubation with GFS extract or mitogens PHA and ConA, for 72 hours the relative uptake of chromium was assessed as a measure of mitogenicity. The lowest concentration of GFS extract tested (25 mcg/ $\mathrm{ml}$ ) exerted a four fold mitogenic effect on $\mathrm{T}$ cells, over $50 \%$ of the mitogenic potency of the known mitogens PHA (six fold) and ConA (seven fold). Paradoxically, increased concentrations of the whole extract showed decreasing effects on mitogenic activity. This may be accounted for by the increasing physical inhibition due to increased viscosity in the culture media, or the increasing concentration of unidentified inhibitory components present in the extract. Results are shown in Figure 1.

Additional studies illustrated little effect on NK cell activity and no effects on L929 fibroblast growth over 24 or 72 hours (results not shown). There was no bacterial contamination of the GFS (results not shown), thus the presence of bacterial lipopolysaccharides (which may also act as mitogens) was ruled out.

\section{Discussion}

This study was carried out to assess the effects of GFS in patient studies and in vitro.

GFS was ingested by patients suffering active or latent Herpes infections. Results indicated firstly, a positive effect on healing, and secondly, inhibition of outbreaks in cases of HSV-1, HSV-2, ACV resistant HSV-2, and zoster. There were no adverse side effects noted, and GFS was well tolerated by all subjects. Reduced pain levels were noted in some cases. 
A particularly noteworthy result in this study was inhibition of an ACV resistant case of HSV-2. HSV-2 is a sexually transmitted disease of increasing incidence [4]. In part, this is due to the fact that partner transmission may occur during asymptomatic shedding [4] or unrecognised minor outbreaks. Suppressive therapies such as ACV have been tested for their ability to inhibit shedding [20]. However, for long-term use, non-toxic alternatives such as GFS may be preferred by patients, who perceive long-term conventional drug use as detrimental. In addition, GFS may reduce the generation of resistant strains which arise through prolonged use of drugs such as ACV.

GFS extract potently inhibited HSV and HCMV infection of human cells, and stimulated human T cell proliferation in vitro. In other studies $[16,17]$ extracts were active against clinical strains of HSV. These mechanisms may be relevant to the observed clinical response.

Human T cell proliferation in vitro observed here concurs with observations by Shan et al [18]. Shan found that in the presence of various seaweed extracts including Undaria, lymphocyte proliferation and cytotoxic $\mathrm{T}$ cell activity was enhanced, but that NK cell activity was not. Cytotoxic $\mathrm{T}$ cells play a prominent role in the immune response in the local environment of HSV-2 infections [21], and have been shown to be key elements of immune defence against HSV-I and other viruses [22,23]. Thus the observed $\mathrm{T}$ cell mitogenic effect caused by GFS in vitro may be related to enhanced immunity in vivo.

Sulphated molecules with similarities to sulphated galactofucan, such as dermatan sulphate have been shown to be present in plasma after oral ingestion [24]. Macromolecules are known to pass through the gut into plasma and into lymph via the extensive gut lymphoid system [25] where they may affect immune function. The gut lymphoid system or 'GALT' comprises Peyers patches and gut cryptopatches where different types of T cells and other immune cells participate in uptake or contact with gut contents. T cell uptake or contact with GFS by either Peyers patch or gut cryptopatch dwelling cells may result in the proliferative response noted here in vitro. However, immune indicators were not measured in this study.

Whilst further research is called for, the results obtained in this study show that ingestion of GFS is associated with resolution, reduced pain and outbreak inhibition of Herpes virus infections. Studies regarding uptake, immunostimulation and anti-viral effects of GFS are in progress.

\section{Conclusions}

The rise in nucleic acid inhibitor resistant strains of HSV2 , and the need for less aggressive anti-viral therapies, in- dicates a role for alternative therapeutic routes such as that demonstrated here for GFS.

Ingestion of GFS has inhibitory effects on reactivation of HSV and positively affects the resolution of active Herpes infections. GFS has inhibitory effects on Herpes infectivity in vitro and a $\mathrm{T}$ cell mitogenic effect in vitro.

The mechanism of inhibition of Herpes infections may be, in part, mediated by galactofucan present in the GFS.

\section{Competing interests}

Russell Cooper, Ken Thompson, John Godwin, Kate Elliot have no declared interests. JH Fitton and Charles Dragar are employed Marine Biomedical Research Tasmania Australia.

\section{Authors' contributions}

RC, JG, KE and JHF participated in clinical studies and JHF drafted the manuscript. KT carried out the in vitro studies. JHF and CD conceived of the study, and participated in its design and coordination. All authors read and approved the final manuscript.

\section{Acknowledgements}

Marine Resources Pty Ltd supplied GFS for this study. Thanks to C Trambas (University of Tasmania) for data on T cell mitogenicity.

\section{References}

I. Field HJ: Herpes simplex virus anti-viral drug resistance - current trends and future prospects. J Clin Virol 200 I, 2 I (3):26I-269

2. Villarreal EC: Current and potential therapies for the treatment of Herpes virus infections Prog Drug Res 200I, 56:77-120

3. Nahmias AJ, Lee FK, Beckman-Nahmias S: Sero-epidemiological and -sociological patterns of Herpes simplex virus infection in the world. Scand J Infect Dis Suppl 1990, 69:19-36

4. Okinaga S: Shedding of Herpes simplex virus type I into tears and saliva in healthy Japanese adults. Kurume Med J 2000, 47(4):273-7

5. Niedobitek G, Meru N, Delecluse H]: Epstein-Barr virus infection and human malignancies Int J Exp Pathol 200I, 82(3): I49-70

6. Morita M, Morishima T, Yamazaki T, Chiba S, Kawana T: Clinical survey of congenital cytomegalovirus infection in Japan. Acta Paediatr Jpn 1998, 40(5):432-6

7. Luscher-Mattli M: Polyanions-a lost chance in the fight against HIV and other virus diseases? Antivir Chemistry Chemother 2000, II(4):249-259

8. Schaeffer DJ, Krylov VS: Anti HIV activity of extracts and compounds from algae and cyanobacteria. Ecotoxicology and environmental safety 2000, 45:208-227

9. Witvrouw M, de Clercq E: Sulfated polysaccharides extracted from sea algae as potential anti-viral drugs Gen Pharmacol I997, 29:497-5II

10. Campadelli-Fiume G, Cocchi F, Menotti L, Lopez M: The novel receptors that mediate the entry of Herpes simplex viruses and animal alphaHerpesviruses into cells. Rev Med Virol 2000 , I0(5):305-19

11. Guiry MD, Nic Dhonncha E: AlgaeBase. World Wide Web electronic publication 200I [http://www.algaebase.org]

12. Mori H, Kamei H, Nishide E, Nisizawa K: Sugar constituents of some sulphated polysaccharides from the sporophylls of wakame and their biological activities Marine Algae in Pharmaceutical Science (Edited by: Hoppe HA, Levring T) Pub. Walter de Gruyter Berlin. New York 1982, 2: 109-|2| 
13. Koo JG, Jo KS, Do JR, Woo SJ: Isolation and purification of fucoidans from Laminaria religiosa and Undaria pinnatifida in Korea. J Korean Fish Soc 1995, 28(2):227-236

14. Hudson JB, Kim JH, Lee MK, DeWreede RE, Hong YK: Anti-viral compounds in extracts of Korean seaweeds; Evidence for multiple activities ] Appl Phycology 1999, 10:427-434

15. Ohigashi H, Sakai Y, Yamaguchi K, Umezaki I, Koshimizu K: Possible anti-tumor promoting properties of marine algae and in vivo activity of Wakame seaweed extract. Biosci Biotechnol Biochem 1992, 56(6):994-5

16. Thompson KD, Fitton JH: Anti-viral activity of Tasmanian seaweed extracts against clinical strains of Herpes simplex virus (HSV). Abstract. 18th Annual Clinical Virology Symposium, April 28 - May I, Florida 2002

17. Thompson $\mathrm{KD}$, Fitton $\mathrm{JH}$ : The mode of action of two Tasmanian seaweed extracts against Herpes simplex virus (HSV). $A b-$ stract. 27th International Herpes virus workshop conference, July 20-26, Cairns 2002

18. Shan BE, Yoshida Y, Kuroda E, Yamashita U: Immunomodulating activity of seaweed extract on human lymphocytes in vitro. Int J Immunopharmacol I 999, 2 I (I):59-70

19. Itoh H, Noda H, Amano H, Zhuaug C, Mizuno T, Ito H: Antitumor activity and immunological properties of marine algal polysaccharides, especially fucoidan, prepared from Sargassum thunbergii of Phaeophyceae. Anticancer Res 1993, I3(6A):2045-52

20. Wald A, Zeh J, Barnum G, Davis LG, Corey L: Suppression of subclinical shedding of herpes simplex virus 2 with acyclovir. Ann Intern Med 1996, I 24:8-15

21. Posavad CM, Koelle DM, Corey L: High frequency of CD8+ cytotoxic T-lymphocyte precursors specific for Herpes simplex viruses in persons with genital Herpes. J Virol 1996, 70:8165-8

22. Sciammas R, Kodukula P, Tang Q, Hendricks RL, Bluestone JA: T cell receptor-gamma/delta cells protect mice from Herpes simplex virus type I-induced lethal encephalitis J Exp Med I997, 185(II): 1969-1975

23. Selin LK, Santolucito PA, Pinto AK, Szomolanyi-Tsuda E, Welsh RM: Innate immunity to viruses: control of vaccinia virus infection by gamma delta T cells. I Immunol 200I, I66( I I):6784-6794

24. Dawes J, Hodson BA, Pepper DS: The absorption, clearance and metabolic fate of dermatan sulphate administered to manstudies using a radioiodinated derivative Thromb Haemost 1989 , 62:945-949

25. Weiner ML: Intestinal Transport of some macromolecules in food. Food Chem Toxicol 1988, 26:867-880

\section{Pre-publication history}

The pre-publication history for this paper can be accessed here:

http://www.biomedcentral.com/1472-6882/2/11/prepub

\section{Publish with BioMed Central and every} scientist can read your work free of charge

"BioMedcentral will be the most significant development for disseminating the results of biomedical research in our lifetime." Paul Nurse, Director-General, Imperial Cancer Research Fund

Publish with BMC and your research papers will be:

- available free of charge to the entire biomedical community

- peer reviewed and published immediately upon acceptance

- cited in PubMed and archived on PubMed Central

- yours - you keep the copyright 